\title{
SPONDYLITIS IN POST-PUBERTAL PATIENTS WITH RHEUMATOID ARTHRITIS OF JUVENILE ONSET*
}

\author{
BY \\ MORRIS ZIFF, VINCENT CONTRERAS $\dagger$, and CURRIER McEWEN \\ From the Department of Medicine and the Study Group on Rheumatic Diseases, \\ New York University College of Medicine
}

(RECEIVED FOR PUBLICATION JANUARY 20, 1956)

The involvement of the cervical spine in patients with juvenile rheumatoid arthritis was mentioned by Still (1897) as among the earliest manifestations of this disease. Middlemiss (1951) has reported that clinical involvement of the cervical spine, though observed frequently, is not as often seen radiologically. Coss and Boots (1946) found fusion of two or more cervical segments in 11 per cent. of their patients with juvenile rheumatoid arthritis. In an analysis of 61 cases, Barkin (1952) and Potter, Barkin, and Stillman (1954) found clinical involvement of the cervical spine in 70 per cent. of individuals, and obtained radiological confirmation in 54 per cent. The most frequent and outstanding radiological change was narrowing, irregularity, and often fusion of the apophyseal joints of two or more cervical vertebrae.

These observations have led us to review the $x$ rays of the spine and sacro-iliac joints of our postpubertal patients with rheumatoid arthritis in whom the disease had begun in childhood. This was done to determine whether it would be possible to utilize the presence of a characteristic type of spondylitis, if found with sufficient frequency in this group, as an aid in the retrospective diagnosis of juvenile rheumatoid arthritis in cases in which evidence of the childhood stage of the disease might have been clinically inapparent.

\section{Material}

Sixteen patients in the post-pubertal age group with rheumatoid arthritis of juvenile onset were studied. Their ages ranged from $12 \cdot 5$ to 50 years (average 23). Twelve were females and four males. Fifteen had had

\footnotetext{
* This work was supported by a grant from the Masonic Foundation for Medical Research and Human Welfare.

$\dagger$ Rockefeller Foundation Fellow. Present Address: Hospital Jose Joaquin Aquirre, University of Chile, Santiago, Chile.
}

the disease for periods ranging from 5 to 47 years, and one had had it for one year. All gave a history of significant peripheral joint involvement in the early stages of the disease. As controls, the available spine $x$ rays of 26 adult patients with clinical rheumatoid arthritis of more than 4 years' duration were reviewed.

\section{Results}

The $x$-ray findings were related to the history, clinical findings, and sensitized sheep cell agglutination titres (Table I, opposite).

Radiology.-One patient (Case 1) showed no significant radiological changes in the spine. Three (Cases 14, 15, 16) demonstrated in addition to peripheral arthritis the characteristic features of ankylosing spondylitis with involvement of the sacro-iliac and apophyseal joints, and calcification of paravertebral ligaments; two of these showed clinical and radiological involvement of the cervical spine of the type seen in this disease. The remaining twelve patients showed, in addition to peripheral arthritis, $x$-ray evidence of fusion of one or more cervical apophyseal joints. Thus, fifteen of the sixteen patients showed some form of spondylitis and fourteen showed cervical spine involvement. This demonstrates the high incidence with which the cervical spine is involved in the later stages of juvenile rheumatoid arthritis.

Fig. 1 (opposite) shows the changes of ankylosing spondylitis which are indistinguishable roentgenographically from the classical adult type in a 50-yearold female (Case 16) whose disease had begun peripherally at age 3 . In addition to the cervical spine there were classical changes in the sacro-iliac joints, apophyseal joints, and paravertebral ligaments, as well as involvement of most peripheral joints. 
TABLE I

CLINICAL AND RADIOLOGICAL FINDINGS AND SHEEP CELL AGGLUTINATION TITRES IN POST-PUBERTAL PATIENTS WITH RHEUMATOID ARTHRITIS OF JUVENILE ONSET

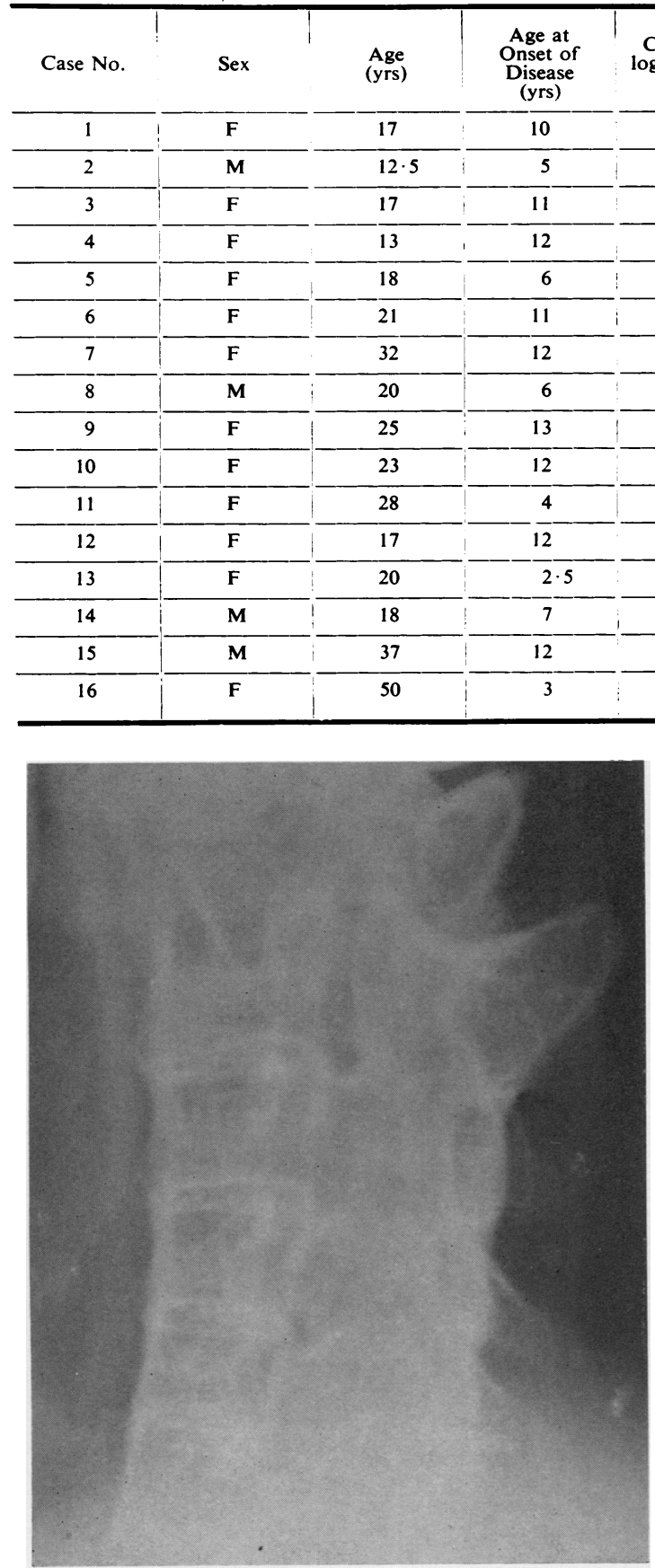

Fig. 1.-Changes of ankylosing spondylitis; slight kyphosis of all apophyseal joints; thinning of all disk cartilages; calcification of paravertebral ligaments (Case 16, Table I).

\begin{tabular}{|c|c|c|}
\hline \multirow{2}{*}{$\begin{array}{l}\text { Clinical and Radio- } \\
\text { logical Involvement of } \\
\text { Cervical Spine }\end{array}$} & \multicolumn{2}{|c|}{ Sheep Cell Agglutination Test } \\
\hline & Euglobin Fraction & Inhibition $†$ \\
\hline$-*$ & Positive & Absent \\
\hline+ & Positive & Absent \\
\hline+ & Positive & Absent \\
\hline+ & Positive & Absent \\
\hline+ & Positive & Absent \\
\hline+ & Positive & Absent \\
\hline+ & . Test not done & Test not done \\
\hline+ & Negative & Absent \\
\hline+ & Negative & Absent \\
\hline+ & Positive & Absent \\
\hline+ & Negative & Absent \\
\hline+ & Negative & Absent \\
\hline+ & Negative & Absent \\
\hline- & Negative & Absent \\
\hline+ & Negative & Present \\
\hline+ & Test not done & Test not done \\
\hline
\end{tabular}

* The spine was involved clinically but not radiologically.

$\dagger$ Absence of inhibition signifies presence of sheep cell factor.

In twelve patients ( 75 per cent.), however, there were isolated cervical lesions in which the most characteristic change was fusion of the apophyseal joint between $\mathrm{C}_{2}$ and $\mathrm{C}_{3}$ (Fig. 2, overleaf), and less often also between $\mathrm{C}_{3}-\mathrm{C}_{4}$, or even at a lower level (Fig. 3, overleaf).

Other radiological findings pointed out by Potter, Barkin, and Stillman (1954) have also been noted in this group, i.e. loss of normal cervical lordosis (Fig. 3), and even kyphosis; underdevelopment of the bodies (Figs 2 and 3); and thinning of the disk cartilages between the cervical vertebrae (Fig. 3). Fig. 4 (overleaf) shows progression of the lesion of the $\mathrm{C}_{2}-\mathrm{C}_{3}$ apophyseal joint in Case 5 during a 4-year period.

In three of the above twelve patients (Cases $2,5,7)$, the cervical spine involvement was accompanied by radiological changes in the sacro-iliac joints consisting of blurring of the joint space and some degree of subchondral sclerosis. Actual obliteration of the joint space was not observed. In Table II (overleaf) details of the radiological findings in the sixteen patients are presented.

Clinical Findings.-Pain and stiffness of the neck at some time were present in all patients but one (Case 14). In most cases, the presentation of 


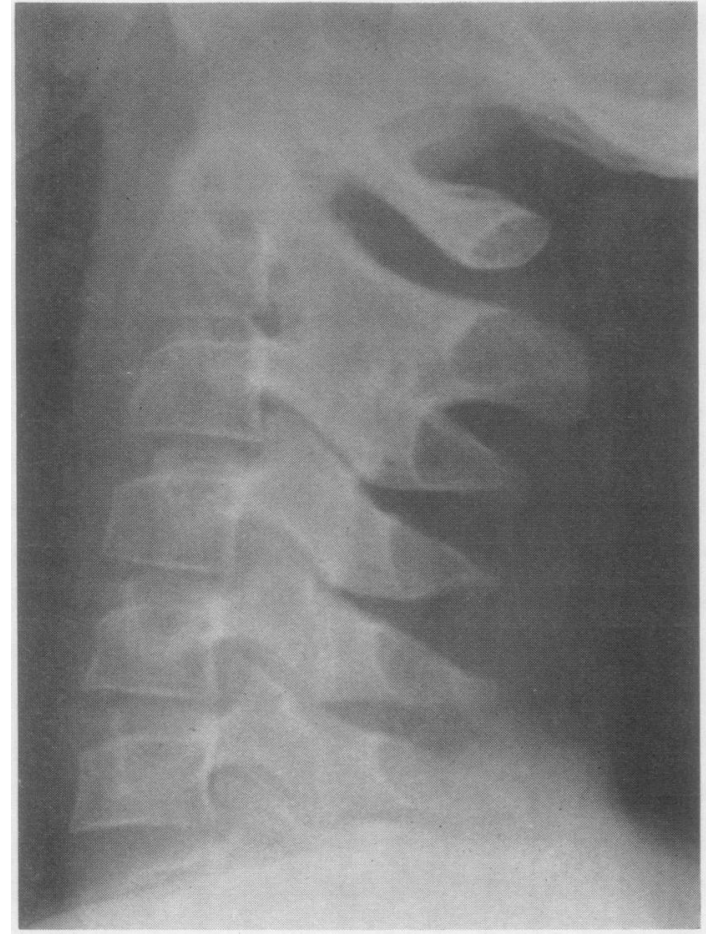

Fig. 2.-Fusion of apophyseal joints between $\mathrm{C}_{2}$ and $\mathrm{C}_{3}$; loss of normal lordosis; underdevelopment of bony structures (Case 2).

symptoms of cervical spondylitis occurred early in the course of the disease; they were the first to be noted in three patients (Cases 2, 8, 9), and in the remainder the symptoms began in the peripheral joints. Significant limitation of motion of the cervical spine, as revealed by history or findings on physical examination, was present at some time in all but three patients (Cases $4,6,14$ ); one of these (Case 14) was the patient with the ankylosing type of spondylitis sparing the cervical spine. The cervical pain usually disappeared after periods ranging from a few months to 4 years after onset, but stiffness and limitation of motion were residual in all the fourteen patients with cervical spine involvement but two (Cases 4 and 6).

Sensitized Sheep Cell Agglutination Titres.-This test was done in fourteen patients using the euglobin fraction for both direct agglutination and for inhibition of known positive sera (Ziff, Brown, Badin, and McEwen, 1954, 1956). Sheep cell agglutination tests were done in eleven of the twelve individuals with isolated cervical lesions. In six of these (Table I), the euglobin fraction, when tested directly, gave a positive result, and in all eleven the euglobin failed to inhibit known positive serum,

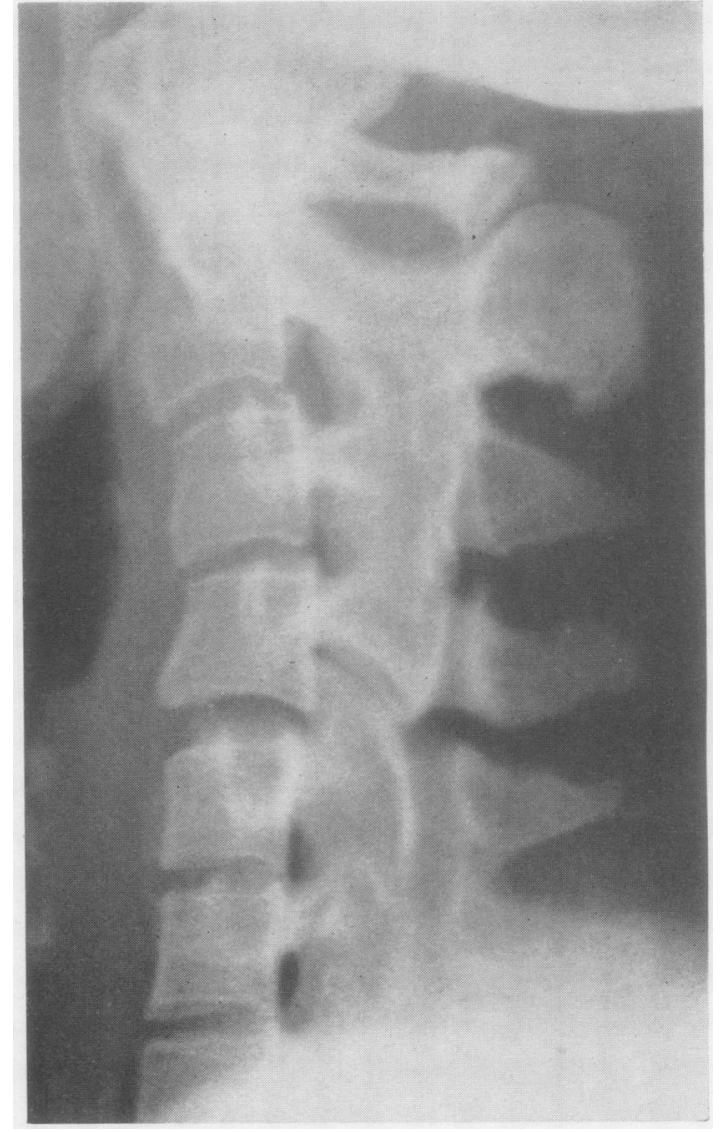

Fig. 3.-Fusion of apophyseal joints between $\mathrm{C}_{2}-\mathrm{C}_{3}, \mathrm{C}_{3}-\mathrm{C}_{4}$, and $\mathrm{C}_{5}-\mathrm{C}_{6}$; thinning of the disk cartilages between the same vertebrae; loss of cervical lordosis; underdevelopment of bony structures (Case 10).

indicating that the sheep cell factor was present.

The sheep cell agglutination test was done in two (Cases 14 and 15) of the three cases presenting the pattern of ankylosing spondylitis. The test was negative in Case 15. Though the euglobin fraction of Case 14 did not show agglutination in a significant titre, it did not inhibit known positive serum, indicating the presence of the sheep cell factor. The patient with no $x$-ray changes in the spine (Case 1) gave a positive sheep cell agglutination test.

Control Series.-We reviewed the $x$ rays of the cervical spines of 26 patients with rheumatoid arthritis in the Out-Patient Clinic of Bellevue Hospital, who were known to the authors individually, and for whom $x$ rays of the cervical and lumbosacral spine, and sacro-iliac joints were available. All had had the disease for more than 4 years and in all cases the disease was known to 


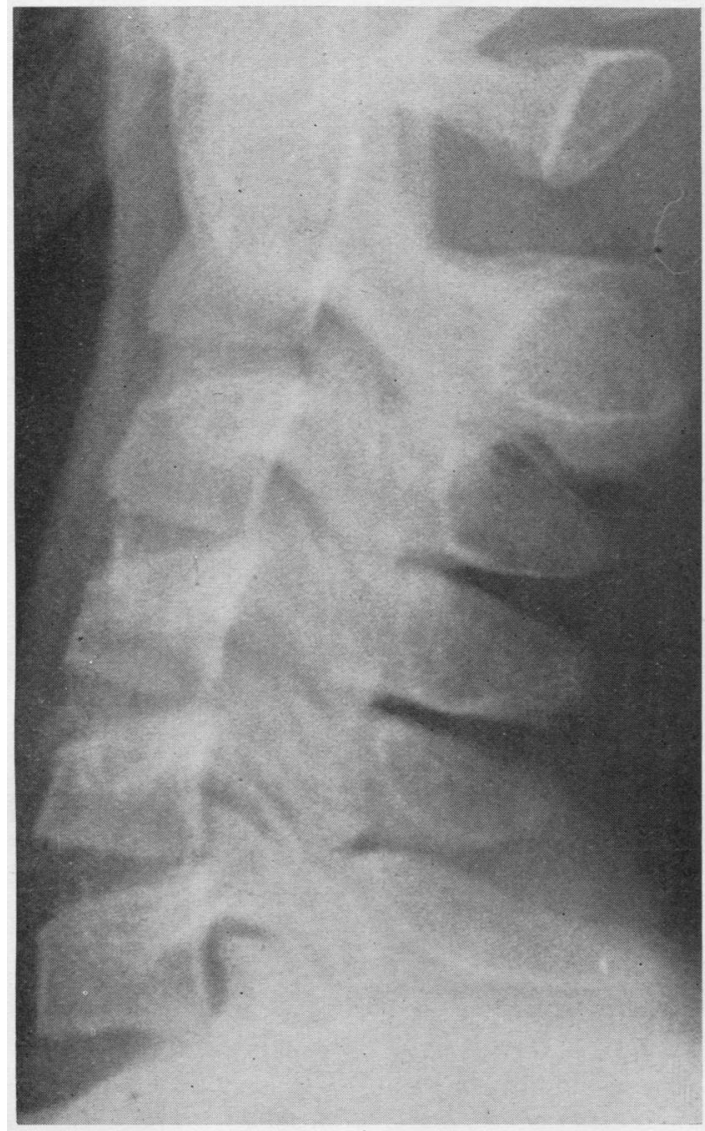

(a)

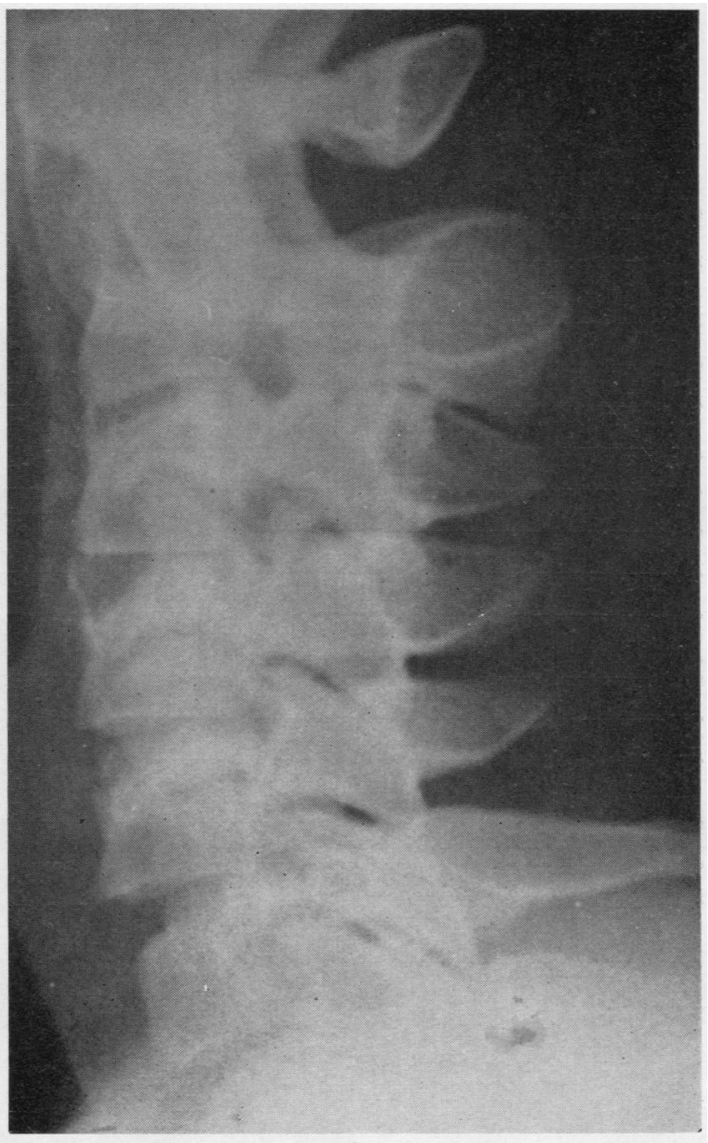

(b)

Fig. 4.-Progression of fusion of $\mathrm{C}_{2}-\mathrm{C}_{3}$ apophyseal joint in Case 5 during a 4-year period. (a) at age $14 ;(b)$ at age 18.

have begun after puberty. Seven were males and nineteen were females, and they ranged in age from 28 to 65 years. In this group, only two showed changes in the spine, and these consisted of fusion of the apophyseal joints localized at $\mathrm{C}_{2}-\mathrm{C}_{3}$ segments.

\section{Discussion}

The results of this study emphasize, as have previous investigations, the frequency of involvement of the spine in the juvenile type of rheumatoid arthritis. This involvement appears to be especially common, however, in the post-pubertal group of such patients, who are in the later stages of the disease. Fifteen of the sixteen patients studied showed radiological evidence of spondylitis of one form or another.

Most commonly this involvement presented itself as fusion of one or more cervical apophyseal joints as found in twelve of the individuals of the present group. The presence of the sheep cell factor in the serum of all these patients who were tested (as indicated by absence of inhibition of positive rheumatoid serum) indicates a relation to the classical type of peripheral rheumatoid arthritis and not to ankylosing spondylitis (Ziff, Brown, Badin, and McEwen, 1954, 1956). This is true in spite of the fact that three showed some degree of sacro-iliac involvement, which when it occurs with ankylosing spondylitis in adults is almost always associated with negative agglutination tests (Ziff and others, 1954, 1956).

In a minority of cases, the juvenile disease, at least as far as the spine was concerned, appeared to follow the pattern of adult ankylosing spondylitis, although peripheral joint involvement was the striking feature early in the disease. This was true in three of the sixteen cases. In such cases, apparently, the cervical spine may or may not become involved in the usually ascending progression of the disease. If the cervical spine is reached, the type of lesion 
TABLE II

RADIOLOGICAL FINDINGS IN SPINE IN POST-PUBERTAL PATIENTS WITH RHEUMATOID ARTHRITIS OF JUVENILE ONSET

\begin{tabular}{|c|c|c|c|c|c|c|}
\hline $\begin{array}{l}\text { Case } \\
\text { No. }\end{array}$ & $\begin{array}{l}\text { Cervical } \\
\text { Fusion }\end{array}$ & $\begin{array}{l}\text { Loss of } \\
\text { Lordosis }\end{array}$ & $\begin{array}{l}\text { Under-development } \\
\text { of Bony Structures }\end{array}$ & $\begin{array}{c}\text { Thinning of } \\
\text { Intervertebral Disks }\end{array}$ & $\begin{array}{c}\text { Sacro-iliac } \\
\text { Involvement }\end{array}$ & $\begin{array}{l}\text { Calcification } \\
\text { of Ligaments }\end{array}$ \\
\hline 1 & - & - & - & - & . & 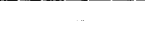 \\
\hline 2 & $\begin{array}{l}\mathrm{C}_{2}-\mathrm{C}_{3} \\
\mathrm{C}_{7}-\mathrm{D}_{1}\end{array}$ & + & + & $\mathrm{C}_{2}-\mathrm{C}_{3}$ & .. & - \\
\hline 3 & $\mathrm{C}_{2}-\mathrm{C}_{3}$ & - & + & - & 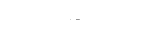 & - \\
\hline 4 & $\mathrm{C}_{2}-\mathrm{C}_{3}$ & + & - & - & - & - \\
\hline 5 & $\mathrm{C}_{2}-\mathrm{C}_{3}$ & + & - & $\mathrm{C}_{3}-\mathrm{C}_{6}$ & $\therefore$ & - \\
\hline 6 & $\mathrm{C}_{2}-\mathrm{C}_{3}$ & - & - & - & - & - \\
\hline 7 & $\mathrm{C}_{2}-\mathrm{C}_{3}$ & + & - & - & + & - \\
\hline 8 & $\mathrm{C}_{2}-\mathrm{C}_{4}$ & + & + & $\mathrm{C}_{3}-\mathrm{C}_{4}$ & - & - \\
\hline 9 & $\mathrm{C}_{2}-\mathrm{C}_{7}$ & + & - & $\mathrm{C}_{2}-\mathrm{C}_{7}$ & - & - \\
\hline 10 & $\begin{array}{l}\mathrm{C}_{2}-\mathrm{C}_{4} \\
\mathrm{C}_{5}-\mathrm{C}_{6}\end{array}$ & + & 4 & $\begin{array}{l}\mathrm{C}_{2}-\mathrm{C}_{5} \\
\mathrm{C}_{6}-\mathrm{C}_{7}\end{array}$ & - & - \\
\hline 11 & $\mathrm{C}_{2}-\mathrm{C}_{3}$ & - & - & $\mathrm{C}_{2}-\mathrm{C}_{3}$ & $\cdots$ & - \\
\hline 12 & $C_{7}-D_{1}$ & + & - & - & $\cdots$ & - \\
\hline 13 & $\begin{array}{l}\mathrm{C}_{2}-\mathrm{C}_{4} \\
\mathrm{C}_{7}-\mathrm{D}_{1}\end{array}$ & - & + & $\begin{array}{l}\mathrm{C}_{2}-\mathrm{C}_{4} \\
\mathrm{C}_{7}-\mathrm{D}_{1}\end{array}$ & $\cdots$ & - \\
\hline 14 & - & - & - & - & $\because$ & $\div$ \\
\hline 15 & $\mathrm{C}_{2}-\mathrm{C}_{7}$ & - & - & $\mathrm{C}_{2}-\mathrm{C}_{7}$ & + & $\div$ \\
\hline 16 & $\mathrm{C}_{2}-\mathrm{C}_{7}$ & $\div$ & + & $\mathrm{C}_{2}-\mathrm{C}_{7}$ & - & .. \\
\hline
\end{tabular}

seen on $x$ ray in this region is the same as that seen in adult ankylosing spondylitis, including calcification of paravertebral ligaments. The two cases in this group on the sera of which there was an opportunity to perform the sheep cell agglutination test are too few to allow any significant application of this test as an aid in deciding whether the group is related to classical rheumatoid arthritis or to ankylosing spondylitis.

The control group of 26 patients with rheumatoid arthritis whose disease began post-pubertally showed fusion of the $\mathrm{C}_{2}-\mathrm{C}_{3}$ apophyseal joint in two instances. The sacro-iliac joints were not abnormal in these patients. It appears, therefore, that though radiological evidence of spinal involvement of the type described may be found in adult rheumatoid arthritis, it is relatively infrequent. It may be that in some cases demonstrating such changes, the childhood stage of the disease had been missed. It appears, from the findings presented, that the presence of localized cervical spondylitis, especially fusion of apophyseal joints, in any particular individual with rheumatoid arthritis, justifies suspicion of a childhood onset of the disease.

\section{Summary}

Sixteen patients in the post-pubertal age group with rheumatoid arthritis of juvenile onset have been studied with respect to involvement of the spine. Clinical and radiological findings and the results of sensitized sheep cell agglutination tests have been correlated.

All patients had peripheral arthritis in the early stages of the disease. Fifteen of the sixteen demonstrated spinal involvement of one form or another, radiologically, at the time of the study. In three patients, this followed the pattern of ankylosing spondylitis as seen in adults, including in two of them the cervical spine. In twelve patients the outstanding change was fusion of the cervical apophyseal joints, especially the $\mathrm{C}_{2}-\mathrm{C}_{3}$ segments. The results of sensitized sheep cell agglutination tests resembled those obtained in adult peripheral rheumatoid arthritis rather than those in adult ankylosing spondylitis.

\section{REFERENCES}

Barkin, R. E. (1952). Bull. rheum. Dis., 3, No. 1, p. 19. Coss, J. A., and Boots, R. H. (1946). J. Pediatr., 29, 143 Middlemiss, J. H. (1951). Proc. roy. Soc. Med., 44, 805. 
Potter, T. A., Barkin, R. E., and Stillman, J. S. (1954). Annals of the Rheumatic Diseases, 13, 364.

Still, G. F. (1897). Med.-chir. Trans., 80, 47.

Ziff, M., Brown, P., Badin, J., and McËwen, C. (1954). Bull. rheum. Dis., 5,75 .

La spondylarthrite des malades pubères atteints d'arthrite rhumatismale à début juvénil

\section{RÉSUMÉ}

On étudia l'atteinte vertébrale de l'arthrite rhumatismale à début juvénil chez seize malades pubères, à la lumière des résultats cliniques, radiologiques et de la réaction d'agglutination des cellules de mouton sensibilisées.

L'atteinte articulaire périphérique exista chez tous les seize malades dès la période de début. A l'examen on décéla des signes radiologiques de l'atteinte vertébrale chez 15 d'entre eux. Chez trois malades cette atteinte correspondit à l'image de la spondylarthrite de l'adulte, y compris l'implication cervicale chez deux d'entre eux. Dans douze cas la fusion des apophyses cervicales, surtout au niveau C2-C3, fut la lésion la plus importante. Les chiffres de la réaction d'agglutination des cellules de mouton s'approchèrent plus à ceux de la polyarthrite de l'adulte qu'à ceux de la spondylarthrite ankylosante de l'adulte.

\section{La espondilartritis en enfermos púberos con artritis reumatoide adquirida en infancia \\ Sumario}

Se estudió el compromiso vertebral de la artritis reumatoide con comienzo juvenil en dieciseis enfermos púberos, a la luz de los resultados clínicos, radiológicos y de la reacción de aglutinacion de las células sensibilizadas de oveja.

Todos los enfermos sufrieron de artritis periférica desde el comienzo de la enfermedad. En quince de ellos el compromiso vertebral en alguna forma fué demostrado radiológicamente al tiempo del estudio. En tres de éstos se trató de la espondilartritis anquilosante semejante a la del adulto, incluyendo en dos de ellos la espina cervical. En doce casos la fusión de las apofisis cervicales, en particular al nivel de $\mathrm{C} 2-\mathrm{C} 3$, fué la lesión la más importante. Las cifras de la reacción de aglutinación de las células de oveja se aproximaron más a las de la poliartritis del adulto que a las de la espondilartritis anquilosante del adulto. 